\title{
The Journal of Neurologì AND Psychopathology
}

Vol. XII.

APRIL. 1932.

No. 48.

\section{Driginal Dapers.}

\section{FAMILIAL BILATERAL AGOUSTIG TUMOURS.* *}

By

LOUIS MINSKI, LoNDON.

With Histopathological Examination by C. GEARY.

\section{INTRODUGTION.}

THE earliest record of bilateral recess tumours in association with central neurofibromatosis was reported by Wishart ${ }^{1}$ in 1882; he regarded them as originating from the seventh cranial nerves. Knobloch ${ }^{2}$ had noted cases as long ago as 1843, but it was not till 1902 that the condition was described in detail, by Henneberg and Kock ${ }^{3}$. Their first case was one of von Recklinghausen's disease with multiple neurofibromata of skin and peripheral nerves, extra- and intradural spinal nerves, of ninth and tenth cranial roots, and bilateral acoustic tumours.

Diffuse neurofibromatosis has long been recognized as a familial disease; in 1882 von Recklinghausen ${ }^{4}$ stated that it was due to 'congenital disposition.'

Cases of bilateral acoustic neurofibromata as a particular form of the disease, with or without generalized fibromatosis, are comparatively rare.

\section{REPORT OF PERSONAL GASES.}

In this series three members of the same generation suffered from the disease; two presented double acoustic tumours (one with generalized neurofibromatosis) and one with neurofibromatosis of the spinal cord only.

* From the Maudsley Hospital, Denmark Hill, London. 
CASE I.

Clinical History.-Mrs. A. G., aged 41, was admitted to the Maudsley Hospital on July 2, 1931, complaining of deafness and difficulty in walking. The previous history was negative. She was a married woman with three children, all of whom were quite healthy. About three years ago she fell and hurt her right eye, since when she had had difficulty in seeing. She noticed no further change until September, 1930, when on going to work one morning she became somewhat deaf. She ignored this and continued working until Christmas 1930. About twelve weeks ago she became totally deaf; to use the patient's own words ' my ears felt tight and a cold feeling stretched inside my head from one ear to the other across my forehead.' She began to have difficulty in walking; she was noticed to stagger and had trouble in grasping things. She also suffered from headache, not localised to any particular region of the head. She stated that tinnitus, worse in the right ear, preceded the deafness and was like the tinkling of bells.

On Examination.-She was a poorly nourished woman with a rather vacant expression. Her mood was somewhat depressed, but at times she treated the examination with undue levity, and showed some degree of 'Witzelsucht.' She was disorientated for place but not otherwise.

Her memory was somewhat impaired for recent events, otherwise good: there was no evidence of delusions or hallucinations.

There were a few small patches of café-au-lait pigmentation over the extensor surfaces of both forearms, like large freckles.

Neurological Examination.-Well-marked papillœedema was present in both eyes, with a few hæmorrhages and areas of exudate. Oscillating horizontal nystagmus was present to both sides. An area of analgesia and loss of appreciation of light touch was present over the right supraorbital region, and one of hyperæsthesia to heat and cold in the right temporal region. Corneal and conjunctival reflexes were absent on both sides. The face was asymmetrical at rest, and the left side moved better than the right; the right side of the forehead wrinkled less than the left and the right orbicularis oculi was weaker than the left. There was complete bilateral deafness; neither the cochlea nor vestibule was in function. A tuning-fork was not heard on the vertex. There was neither air nor bone conduction, and no response to rotation or caloric tests. She suffered from vertigo and tended to fall chiefly to the right and backwards. Speech was slurred and tenced to be staccato; syllables were missed out.

Rombergism was marked and was unchanged with eyes open. Her gait was markedly ataxic and the movements were jerky. There was no paresis, wasting or fibrillation of the arms or legs, but both were markedly ataxic; intentiontremor, adiadochokinesis and cerebellar defect of movements were present. Past-pointing was present in both hands and spontaneous deviation on the right side. All the deep reflexes were equal in the arms and greatly increased. Sensation was normal in the arms but thermal sensation was impaired in the left lower leg. The deep reflexes in the legs were all increased and equal, double ankle clonus was present and the left plantar was extensor. The abdominal reflexes were all absent. No sphincter impairment was found. Writing was jerky and tremulous. There was no aphasia, apraxia or astereognosis. Right lumbar scoliosis of the trunk was remarked.

Laboratory Examination.-Blood W.R. and Meinicke negative. Blood urea $15 \mathrm{mgrm}$. per cent. Blood count : 4,160,000 reds : Hb. $11 \cdot 8 \mathrm{grm}$. per cent. Colour index : 0.9; whites: 12,000; polymorphs 67 per cent.; lymphocytes 28 per cent.; hyalines 3 per cent.; basophils 1 per cent.; eosinophils 1 per cent. 
Urine normal.

X-ray of head showed an area of calcification to the right of the mid-line (see fig. 1).

The spinal fluid was not under pressure but was slightly turbid. W.R. negative; no increase of cells. Protein $50 \mathrm{mgrm}$. per cent. Lange: 4433210000. Pandy: positive. Blood pressure: 130/90. Arteries thickened.

Course.-Patient complained of increasingly severe headache, became incontinent of urine and died on August 15, 1931.

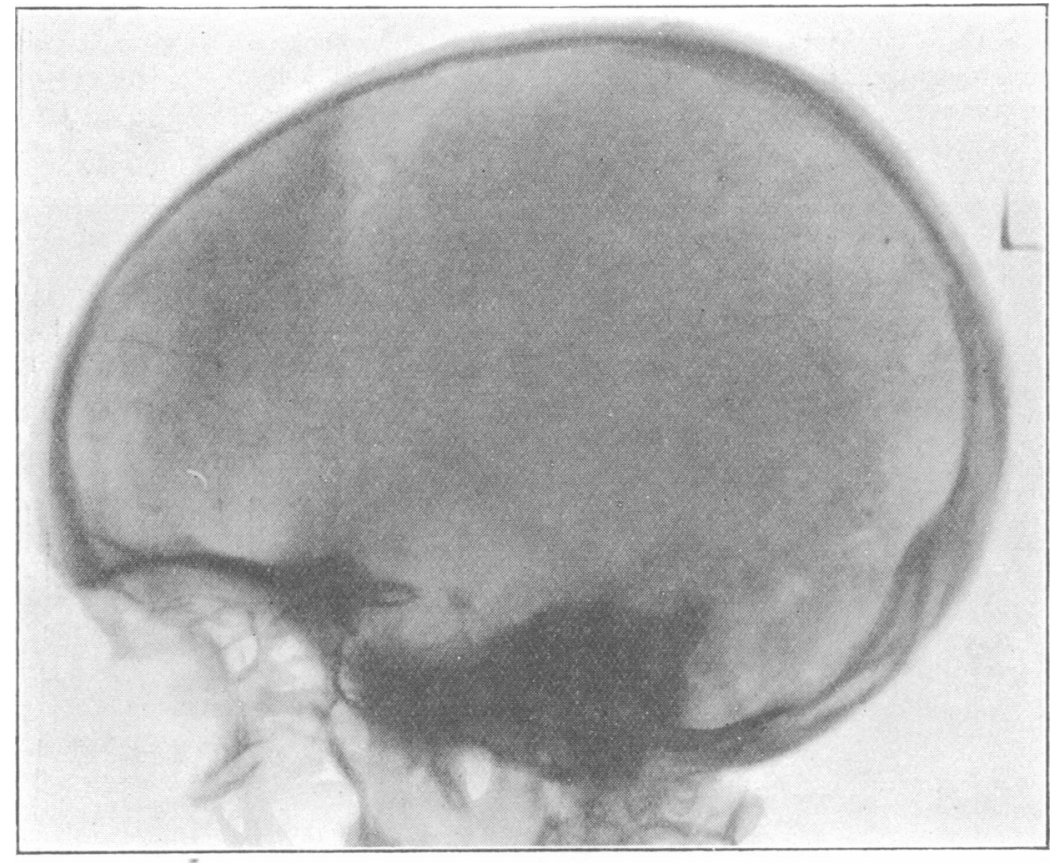

Fig. 1. -X-ray of head of Case I. showing area of calcification to the right of the mid-line.

\section{CASE II.}

Clinical Histary.-The patient E. B., aged 34, was admitted to the Maudsley Hospital on July 13, 1931, suffering from deafness and difficulty in walking. The previous history was normal. He was a married man with three children, one of whom is mentally defective. Ten years ago he knocked his left elbow and developed two 'lumps' over the left olecranon. These were removed, together with an osteoma of the third rib. The former were examined and found to be neurofibromata. No further change occurred until two years ago when he began to develop 'lumps' on the arms and legs.

Two and a half years ago he began to become deaf, and this deafness has increased, especially in the right ear. He is now almost totally deaf. He also has buzzing tinnitus in both ears. At times he feels giddy and tends to fall forwards. Two years ago he also began to have weakness in both hands and the right leg, and 
had to give up work. The 'lumps' are painful, 'like toothache in the arms'; he has tingling and numbness especially at nights.

On Examination.-A poorly nourished man, rather depressed as a result of the pain and insomnia. Memory and orientation were correct and there was no evidence of delusions or hallucinations.

Distribution of neurofibromata.-One the size of an egg was present on right common peroneal nerve and some small ones were found on the right lower limb. There were one each over the left common peroneal and anterior tibial nerves and several smaller ones on the left lower limb. Both ulnar nerves were thickened and on the left was a swelling the size of an egg. There were many on both arms, ranging from the size of an egg to a small pea. They were also present in the interosseous spaces, over the sternomastoid, in the left axilla, supraclavicular region, over the thyroid cartilage and behind the left ear. Both vagi appeared to be beaded and thickened.

All the tumours were hard, firm, and definitely encapsulated. They were not

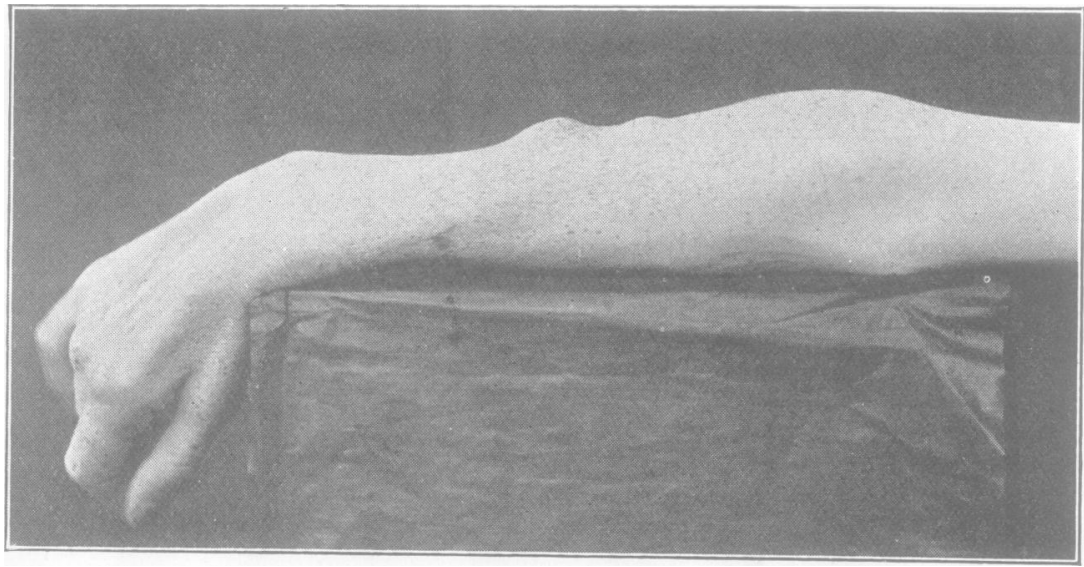

FI(x. 2. - Photograph of arm of Case II. showing nodules, pigmentation and wasting of small muscles of the hand.

pedunculated, and moved transversely but not horizontally. Those over the ulnar and peroneal nerves were painful and produced numbness and tingling in their areas of distribution. There was marked patchy café-au-lait pigmentation over the back of the neck and extensor surfaces of both forearms in the form of freckling (fig. 2). It was present also on the back, upper arms and anterior aspects of both thighs, but not to such a marked extent.

Neurological Examination.-Thermal anæsthesia was found in left supraorbital region; the left conjunctival reflex was absent. Left lower face moved less than right; tremor of left face and fibrillary twitching of left eyelid were present. Shouting was heard in left ear only. Weber: referred to left. Rinne : right, not heard by bone or air; left, negative. Bone conduction in left only. Rotation tests: no response; caloric tests : no reaction either side; past-pointing not marked, only a little inaccuracy on right side.

Labyrinthine function completely lost on right side. Static labyrinth in abeyance left side; still some cochlear function. Tongue tremulous, deviating slightly to right side, 
Rombergism present; tended to fall in any direction. Gait not ataxic; walked with limp due to neurofibroma behind knee. Weakness of both hands; left greater than right. Extension of wrists weak. Wasting of interossei and muscles of thenar eminences present, more marked on left side. Fibrillary twitchings present in extensor and flexor muscles of both forearms. Intention tremor of

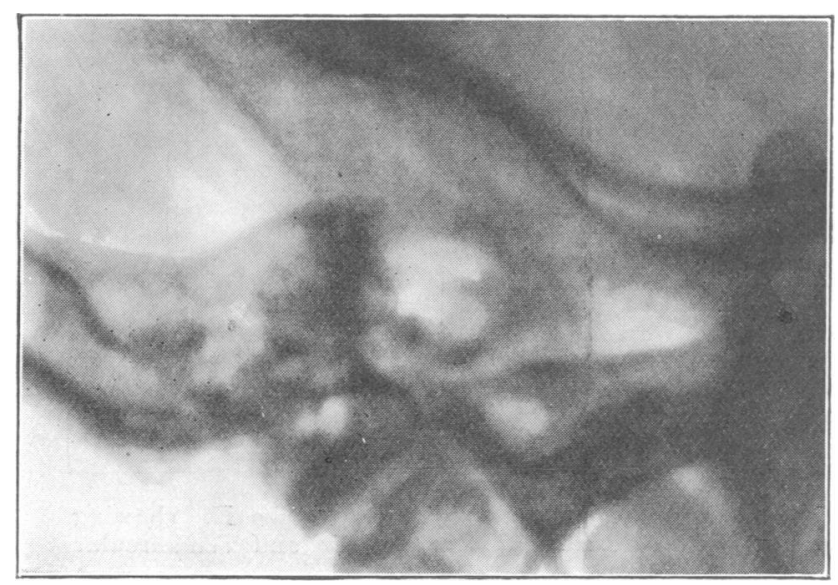

Frg. 3.-X-ray of right labyrinth of Case II. showing expanded internal auditory meatus and destruction of semicircular canals.

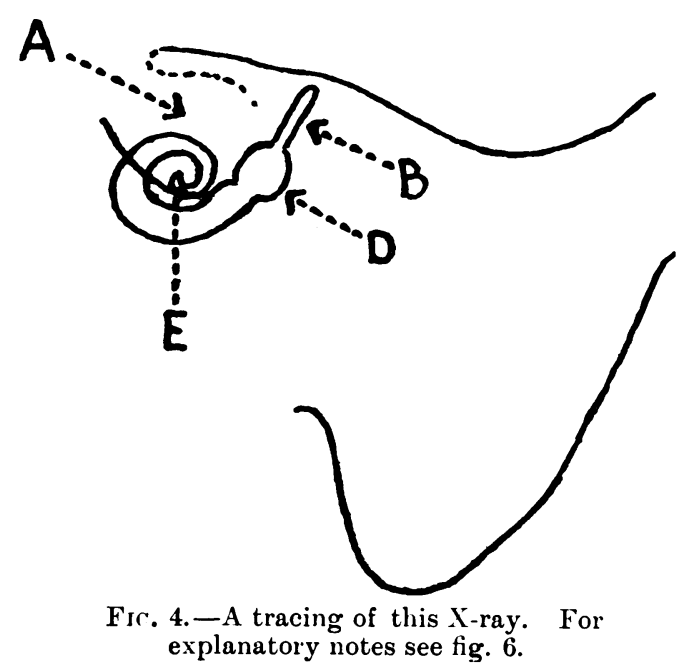

hands present. Patchy analgesia to pin prick present in both hands and arms, more marked on left side. Patchy thermal anæsthesia in same distribution also. Right biceps jerk present, left sluggish, all other deep arm reflexes absent. Wasting of right thigh and leg muscles. Extension and flexion of right knee and plantar and dorsiflexion of foot weak, 


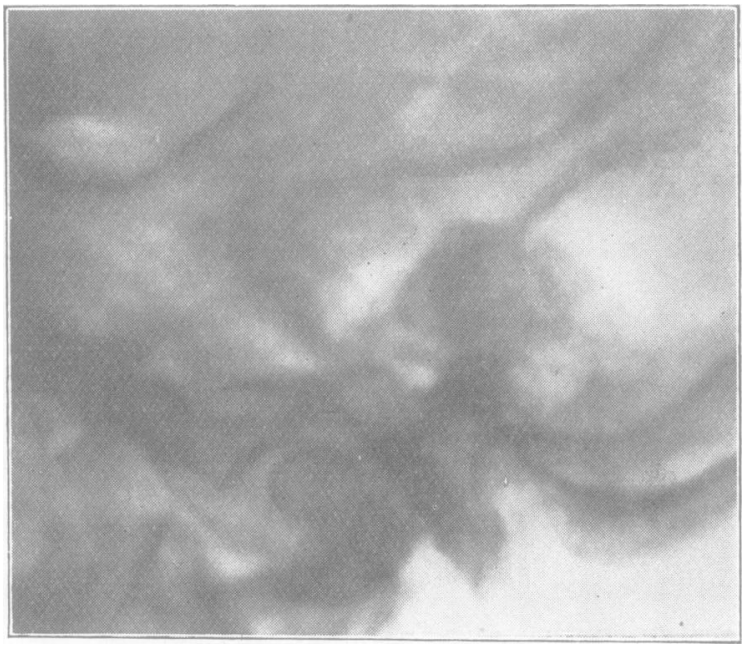

FIG. 5. - X-ray of left labyrinth of Case II. showing destroyed internal auditory meatus and semicircular canals.

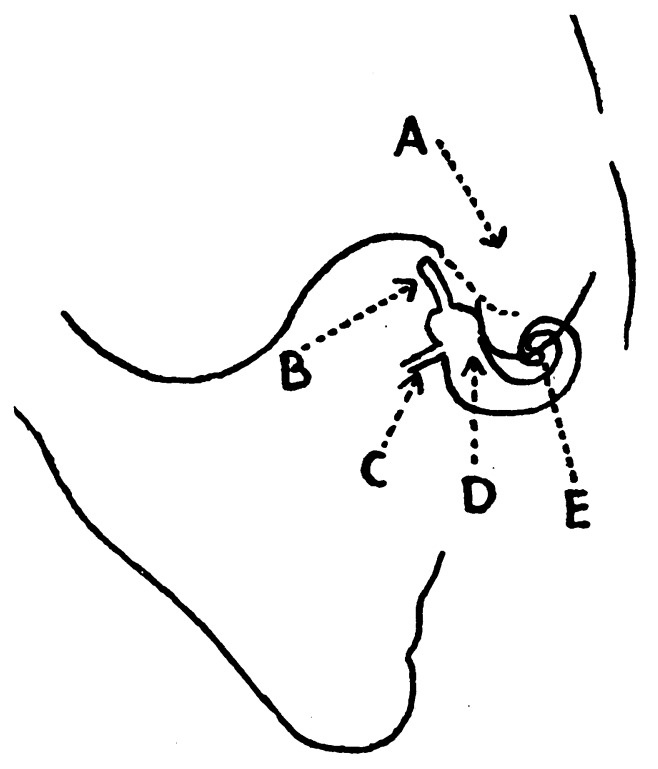

Fig. 6. - A tracing of the X-ray of fig. 5 .
A Destroyed interual meatus
B Superior canal
C External canal
1) Vestibule
E Cochlea 
No cerebellar signs in arms or legs. Vibration sense and light touch absent in right lower leg. Thermal sensation impaired in both legs and feet from knee downwards. All deep reflexes in legs absent. Right plantar equivocal. Abdominal reflexes all sluggish and right lower one absent.

Pes cavus right foot: both feet cold and blue.

R.D. or partial R.D. present in extensors and flexors of right forearm; cxtensors and flexors of wrist and fingers; interossei; and extensors of right knee and left foot. Present in left palmar interossei and intrinsic muscles of foot.

Laboralory Examination.-Blood W.R. and Meinicke negative. Blood urea 13 mgrm. per cent.

Urine normal.

Blood count: reds: 5,200,000. Hb. $12 \cdot 6 \mathrm{grm}$. per cent. Colour index : $0 \cdot 9$. Whites : 6, 400 ; polymorphs 73 per cent.; lymphocytes 24 per cent.; hyalines 5 per cent.

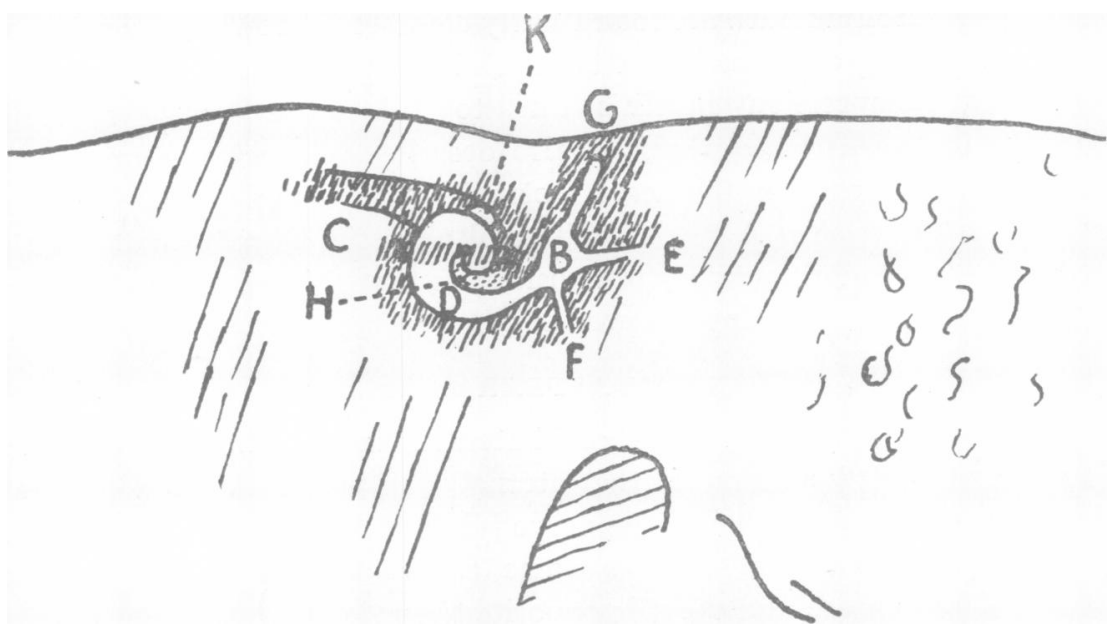

Fig. 7.-Tracing of X-ray of normal lahyrinth for comparion (after H. (iraham Ho:Igson).

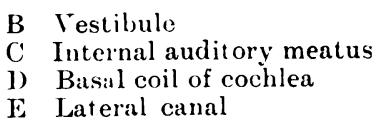

F Posterior canal (lowerend)

(; Superior canal

I Nodiolus

E Lateral canal K Serenth nerre opening

Spinal fluid not under pressure and clear. W.R. negative; cells 3 per c.mm. Protein : $200 \mathrm{mgrm}$. per cent. Lange: $\mathbf{5 5 5 5 5 5 4 3 2 1}$ (excess of globulin over albumin). Blood pressure : $125 / 85$.

X-ray of skull showed that the right internal auditory meatus was very much expanded : on the left side it was completely absent. The appearances suggested bilateral eighth nerve tumours (see figs. 3, 4, 5 and 6).

Course.-The patient gradually became more deaf and had greater difficulty in walking; left face was extremely weak; left eyelid did not blink. Horizontal nystagmus was noted : slow phase to left and quick to right. Double optic atrophy was present.

CASE III.

The youngest boy died at the of 15 and the facts relating to him were as follows. Eight months prior to his death he began to have progressive loss of power in the left arm and leg. Later partial loss of 
power in the right arm developed, followed by wasting. Incontinence of urine supervened. These symptoms were said to have followed a fall on his shoulder one year previously. Thermal sensation in the hands was affected and the deep reflexes were exaggerated. The boy became thin and wasted; the small muscles of the hands were wasted, also the forearms. Deep arm reflexes were absent. Marked spasm of both legs were present. Deep reflexes were increased in the legs; abdominal and cremasteric reflexes were absent. Plantar responses were doubtful. He gradually became weaker, became incontinent of urine and fæces. A double extensor response and ankle clonus were present. Scnsation to touch was impaired from three inches above the umbilicus downwards. The abdominal muscles were weak and spastic paralysis was present in legs. A post-mortem examination was held; the dura was found adherent from the seventh dorsal vertebra to the lower border of the third cervical. The tumour involved the motor roots principally, but had invaded sensory roots on the right side.

Unfortunately there is no report of a microscopic examination of the tumour. Neurofibromata are found fairly commonly growing from the nerve roots and causing compression of the spinal cord. Alexis Thomson ${ }^{5}$ reports a case of compression myelitis due to this cause, with generalized neurofibromata. Other authorities also describe cases where tumours have been found growing from the nerve roots with generalized neurofibromatosis; but just as the patient A. G. had bilateral acoustic neurofibromata without generalized neurofibromata the supposition is that this patient suffered from the same condition affecting the cord only.

\section{X-RAY APPEARANGES.}

$\mathrm{X}$-ray of the head in cases of bilateral acoustic tumours often shows enlargement and distension of the internal meatus, as the tumour usually originates from that portion of the nerve lying within the canal. Henschen ${ }^{6}$ showed, as did Cushing, that in some cases of unilateral tumours this distension may be seen on the side opposite to the lesion. Graham Hodgson ${ }^{7}$ has found that X-ray of the head in cases of eighth nerve tumours may show destruction of the labyrinth and semicircular canals.

Case II shows these features very, well. On the left side the internal auditory meatus is completely absent and destruction of the semicircular canals has taken place (see figs.).

\section{BONY GHANGES.}

Bone changes in neurofibromatosis are fairly common and Brooks and Lehman $^{8}$ have described these in some detail. They describe scoliosis, abnormalities of growth and irregularity of the shafts of long bones appearing in X-ray films as subperiosteal cysts. Microscopic examination of the bone cysts shows the central portion to be composed of tissue similar to that in skin tumours with new-formed bone trabeculæ. These cysts are due to neurofibromata of bone in the periosteum setting up reaction, with resulting bone destruction and regeneration. A thin layer of bone is then formed over 
the tumour if the osteogenetic element of the periosteum comes in contact with it, and so gives the X-ray picture of a subperiosteal cyst.

If the tumour growth involves the epiphyseal cartilage an abnormally short bone may result. If it involves the shaft and if it is associated with hyperplastic change in the lymphatics the entire bone is rendered more porous and plastic. This causes growth in length of the bone, which is distributed throughout the entire bone instead of being confined to the region of the epiphyseal cartilage.

Weiss $^{9}$ described scoliosis in 15 cases and Ashton ${ }^{10}$ a case of neurofibromatosis with spontaneous fractures. Parkes Weber ${ }^{11}$ agrees that bone changes in this disease are due to neurofibromatous involvement of the periosteum. It is interesting to note that in Case II an osteoma was removed from the ribs several years ago. The patient had a right pes cavus and a tendency to the same condition in the left foot. In Case I the patient showed a right lumbar scoliosis, but no other changes in the osseous system, while the father had one leg shorter than the other. The long bones of both patients were X-rayed for evidences of subperiosteal cysts, etc., but no abnormal appearances were found.

\section{HEREDITY AND ETIOLOGY.}

Preiser and Davenport ${ }^{12}$ collected thirty cases of a familial type in which two or more members of a family were affected. According to them the disease seems to reappear in both sexes of successive generations, in accordance with Mendelian law. It must, therefore, be assumed that there is a defect in the germ-plasm which leads to the production of tumours of the nerve under appropriate stimulation. These stimuli are said to be irritation from clothes, infections, pregnancy and endocrine disturbances, but in many cases the tumours are already present and only increased by these factors.

Gardner and Frazier ${ }^{13}$ described a family of five generations with 217 members, 38 of whom had bilateral deafness. They state that since 1915 only 18 verified cases of bilateral acoustic tumours associated with neurofibromatosis have been described, and two without other generalized signs. Henschen ${ }^{14}$ collected 24 cases of bilateral tumours, 19 of which were associated with other evidences of von Recklinghausen's disease, thus making a total of 37 cases with neurofibromatosis and seven which were unassociated with other signs of the disease. Cushing ${ }^{15}$ collected 13 cases of bilateral tumours of the auditory nerves and dural tumours also. Unilateral tumours are much more common. Penfield ${ }^{16}$ has separated the two types on a pathological basis. The isolated tumours contain nerve-fibres in the capsule only, but in the case of neurofibromatosis nerve-fibres in practically all the cases penetrate the tumours, which constitute true neurofibromata. Skinner ${ }^{17}$ stated his belief that the type-cell of these tumours is the neurilemma 
sheath cell, and gave reasons for showing that they existed in unusual numbers on the vestibular portion of the nerve. Henschen stated that the tumour originated on the vestibular portion of the nerve and Gardner and Frazier in their series demonstrated this also. Cushing ${ }^{18}$ states that six per cent. of all intracranial and 20 per cent. of posterior fossa tumours are acoustic in origin and gives the ratio of 1 bilateral to 100 unilateral tumours. He considers that the tumour lies in the internal auditory meatus, which is enlarged on the side of the tumour. He also states that the tumours are closely akin to the peripheral tumours of Recklinghausen's disease and differ only in their greater tendency to the formation of glia-like areas and in the absence or extreme rarity of myelinated or bare nerve-fibres.

Many authorities regard these tumours as being due to an anlage and of embryonal origin; Sternberg ${ }^{19}$ attributed them to an anlage of glia tissue which might be either in the nerve itself or outside of it, thus explaining the cases in which the nerve spanned rather than traversed or became lost in the substance of the tumour. Orzechowski ${ }^{20}$ believes that cerebellopontine angle tumours arise more often from an anlage of the middle wall of the recess than from the nerves. Cushing disagrees with Penfield in regard to the histology of these tumours and states that unilateral tumours are related to bilateral tumours with Recklinghausen's disease, as their histology is identical; and that in all probability they are due to the same underlying anlage which may be regarded as more likely to occur in the eighth than the other cranial nerves.

Collagen fibres in a tangled mass are found in the tumours, like the connective-tissue fibres which run in the endoneurium of a normal nerve parallel to the nerve bundles. In view of the presence of connective-tissue increase about the fibres of the nerve, Trotter $^{21}$ suggested that these tumours appear because of a lack of proper insulation of the nerve fibres themselves with a resultant stimulation of connective tissue. He suggests that nervous tissue is normally insulated by specialized cells and when this insulation is inadequate the nervous tissue acts as an irritant. Herxheimer and Roth had previously maintained that the pathological process involved was a dystrophy or hyperplasia of nervous tissue resulting from the weakness of some specific element and that the connective-tissue growth was of the nature of a reaction.

Several authorities have described endocrine disturbances with diffuse neurofibromatosis. Kawashima ${ }^{22}$ described a case of suprarenal tumour in one case and Tucker reports nine cases associated with endocrine disturbances, viz., one with persistent thymus, three with acromegaloid manifestations and in seven cases there was excessive pigmentation and low blood pressure, denoting suprarenal involvement. Roubinovitch and de la Sourdière $\mathrm{e}^{23}$ found acromegaloid changes in a mother and son with neuro- 
fibromatosis. Barber and Shaw ${ }^{2-4}$. reported a case with bilateral optic atrophy, sexual precocity and a shadow in the sella turcica thought to be that of a tumour (not confirmed). Leir ${ }^{2.5}$ found dystrophia adiposogenitalis with X-ray and ophthalmoscopic changes suggesting pituitary tumour (not confirmed).

These endocrine disturbances associated with neurofibromatosis appear to be too rare and inconstant to be seriously considered etiologically.

From the above accounts it will be seen that the familial characteristics of diffuse neurofibromatosis and double acoustic tumours are well known and are thought by many to be due to some defect in the germ-plasm.

The three patients described had another brother who died suddenly in boyhood, but unfortunately the cause of death was not known. Both patients (Cases I and II) had three children each, and apart from the fact that the youngest child of the second is a mental defective they are all alive and well. The father of the generation described is alive, age 70, and has been a cripple from birth, but no other signs of neurofibromatosis could be found in him, or any other members of the family who were examined. In addition careful enquiry into the histories of members of the family not seen produced no evidence of the disease.

\section{MORBID ANATOMY AND HISTOLOGY.}

The histology of the tumours was first studied by Virchow ${ }^{26}$ who considered them neuromata. In 1881 von Recklinghausen"i named them fibromata and in 1896 Pierre Marie considered that the tumours of the nerves and the skin differed in that the former arose from the sheath cells and the latter from the fibrous tissue of the skin. In 1900 Alexis Thomson ${ }^{2 *}$ stated the tumours arose from the endoneurium. Durante ${ }^{29}$ considered that the tumour arose from the proliferation of the sheath cells or, as he called them, the 'cellules segmentaires' which according to his view formed the axis-cylinder, and he named the tumours ' neuromes vraies segmentaires.' He noted also ' large polygonal multinucleated cells' and ' stellate cells with elongated nucleus' in the more myxomatous part of the tumour.

Verocay $^{30}$ reviewed the subject and considered that the cells composing neurofibromata were undifferentiated neurocytes, capable of giving rise to ganglion or glial cells or to cells of the sheath of Schwann. The tumours of the acoustic nerve he considered to be in their histological characteristics neurofibromata. He called all these forms of tumour ' neurinomata' (nerve thread tumours). Cushing ${ }^{31}$ considers that tumours of the eighth nerve arise from undifferentiated cells at the junction of the glial elements with the sheath of Schwann. This takes place. 
at a considerable distance from the brain-stem, which is probably greater in the vestibular than the cochlear nerve. This ' transition zone' is probably an area of unstable equilibrium and may be more so in the eighth nerve than in the other cranial and spinal nerve roots, as it is to be noted that most cases of multiple tumours of the nerve roots (central neurofibromatosis) are associated with bilateral acoustic tumours. In Verocay's case and in one of Cushing's ganglion-cells were found in acoustic nerve tumours. Verocay considers them to be an integral part of the tumours and Cushing agrees (previous writers considered them to be pre-existing ganglion-cells in relation to the nerve). Cushing remarks that tumours of the nerve tend to show hyaline degeneration of vessel walls and states that impoverishment of blood-supply may result in fibrosis and deposition of calcareous salts in fibrous tissue. This indicates that cases of multiple psammomata of the nerve roots are neurofibromatous in origin. Cushing also states it is not unusual to have multiple endotheliomata of the cerebral and spinal meninges present in cases of central neurofibromatosis.

Greenfield $^{32}$ states that the tumours are composed of cells which resemble the connective-tissue type in having an elongated nucleus and cytoplasm which tails off into a spindle-shaped process at either end, but which differs from it in staining reactions, e.g., with van Gieson's stain, which gives the process more of a brick-red colour than the pure fuchsin staining of connective-tissue. The cells have a tendency to palisading (Cushing), nucleus lying by nucleus and cytoplasm by cytoplasm, giving a banded appearance to the section. Greenfield goes on to say that in addition there are areas of a looser texture in which multinucleated cells are common and the ground substance formed of small rounded cells and scanty cytoplasm which tends to run off into several thin poorly formed processesa type of cell suggesting myxomatous or glial tissue. No nerve fibres were found by silver-staining methods in any of the tumours examined.

Gamper $^{33}$ in an article on the pathology of the central nervous system in this disease found neurinomas of the vagi, multiple gliogenous tumours of the ventricles, two subependymal tumours of neurinomatous structure resembling glial infiltration in the region of the spinal root and ganglion of the left fifth nerve. He described accumulation of pigment with proliferative changes in the glia of the reticular zone; also blastomatous cell proliferation and diffuse loss of myelin fibres in circumscribed areas of the frontal lobes and cerebellum. Nodules like those of nodular sclerosis were found in the cerebellum. The meninges were thickened and there were angiomatous formations on the blood-vessels.

\section{PATHOLOGY OF PERSONAL GASES.}

CASE I. Macroscopic appearances of the growths.-When the brain was removed and examined, two growths were found in the right and left 
cerebellopontine angles respectively, that on the right side being the larger of the two (fig. 8). Owing to the situation of the growths the seventh, eighth, ninth and tenth cranial nerves on both sides were concealed, and it was only by slightly raising the growths that these nerves could be seen, flattened and pressed against the sides of a deep depression formed by the growths. Both tumours were easily detached and seemed to be retained in position by thin strands of arachnoid. Superficially no direct connection

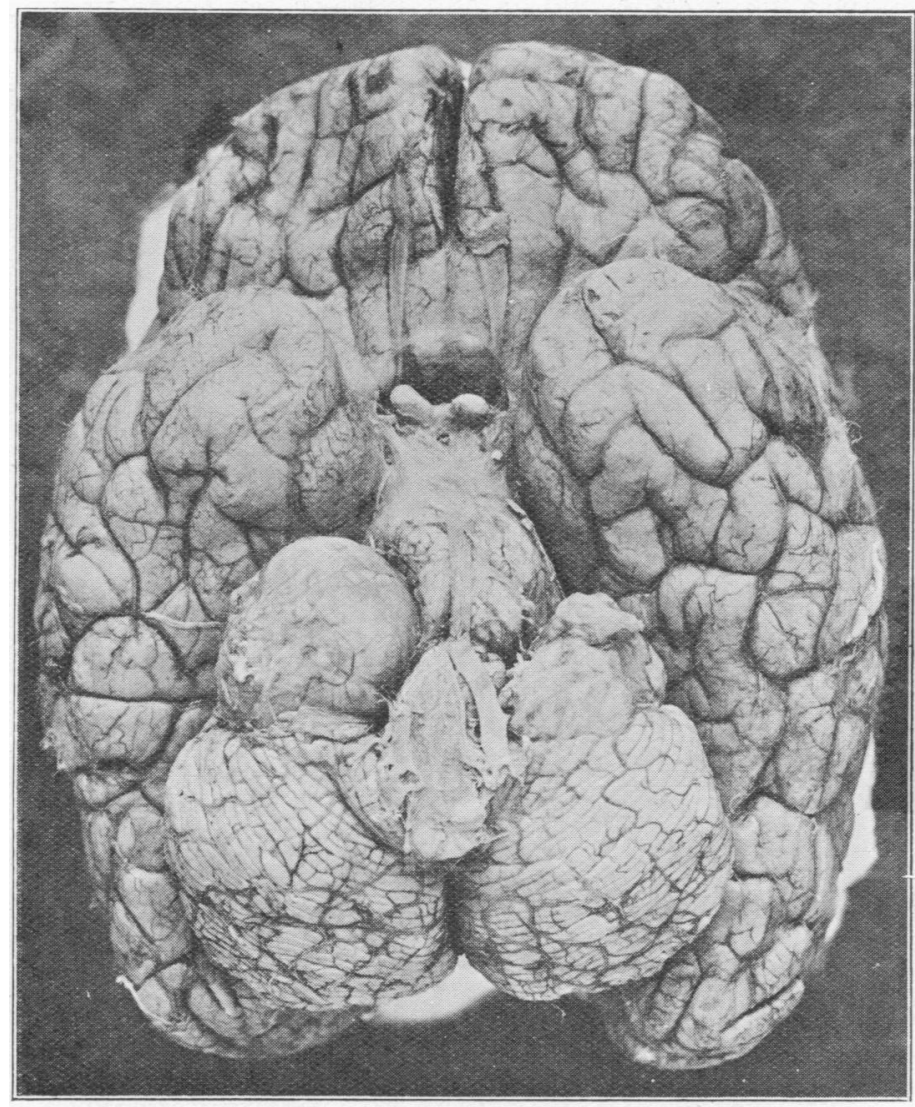

FIG. 8.

could be established between them and the underlying cranial nerves. The latter were quite free and did not appear to have been attached to them, although it is quite possible that owing to the position of the growths, lying on the nerves, any slender connection may have been severed during removal.

The weight of the tumour on the right side was 25.5 grms.; the left, 8.5 grms. The large growth on the right side was found to be very soft and cystic. After suitable hardening it was sectioned and found to consist 
of a large core of coagulated material resembling colloid, with a thin capsule of tissue enveloping it. In one part this capsule was slightly thickened and a section of this showed it to be neurofibromatous in appearance. The smaller growth was of a firm nature throughout with the exception of one or two very small cysts in the centre.

The growth on the right side had formed a deep circular fossa affecting principally the middle and lower thirds of the pons and the anterior part of the cerebellum exposing the middle and inferior cerebellar peduncles, and

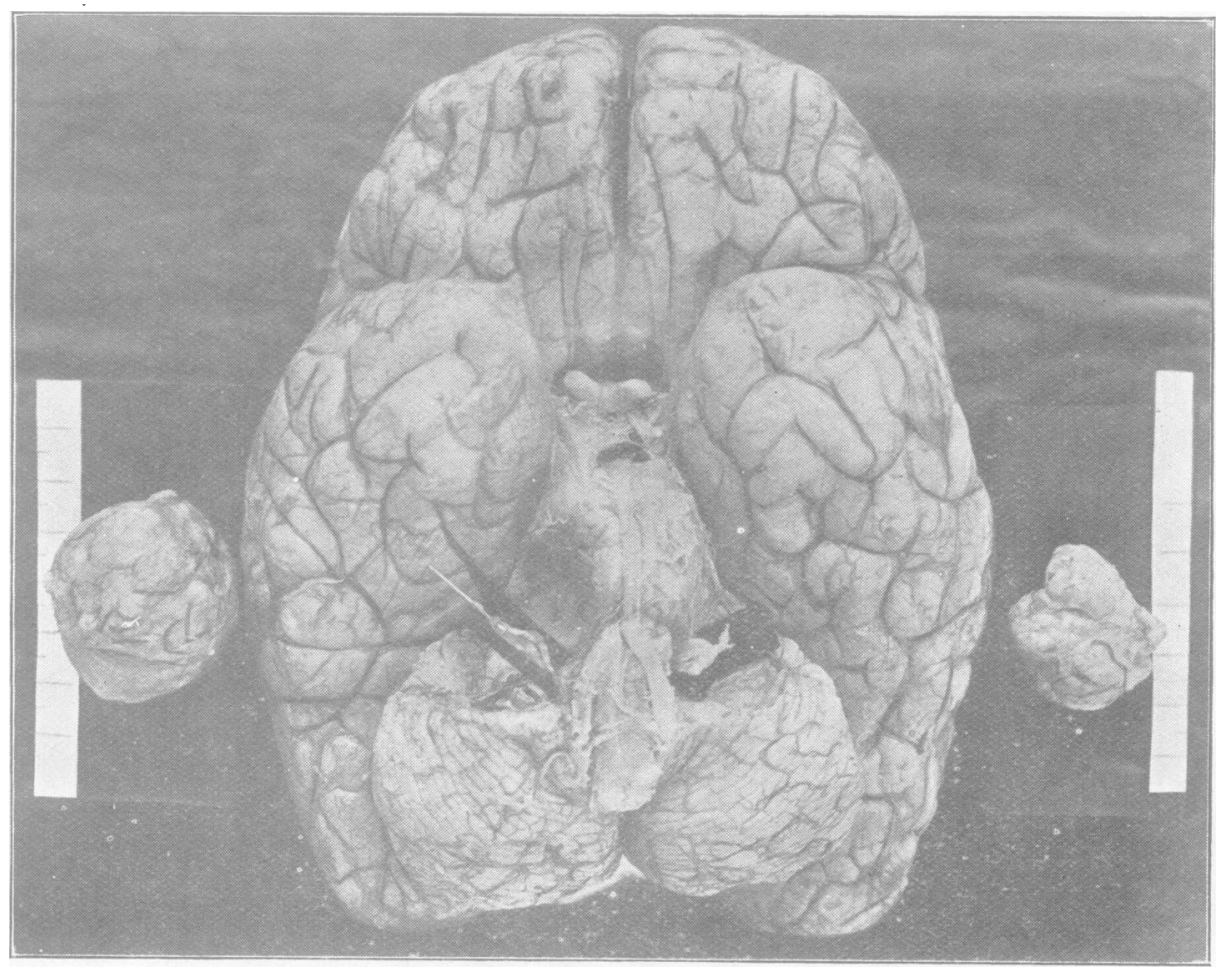

Fil: 9.

had pressed on the lateral aspect of the medulla causing distortion of the pyramid and inferior olivary body (fig. 9). The growth on the left had not formed such a deep fossa, and the damage seemed to be limited to the anterior part of the cerebellum and the middle and inferior cerebellar peduncles.

In addition to the two large growths described, a number of small nodular growths were found affecting the following cranial nerves. On the left side: seventh nerve, small nodule $1 \mathrm{~mm}$. in diameter; eighth nerve, several small nodules, one of which was about $3 \mathrm{~mm}$. in diameter; twelfth nerve, small nodule $2 \mathrm{~mm}$. in diameter. 
On the right side, owing to the pressure of the large growth combined with the depth of the fossa it was found difficult to identify with accuracy the seventh and eighth nerves, but on one of these nerves, presumably the eighth, there were several small nodules, which had coalesced and matted the branches together, forming an elongated growth $5 \mathrm{~mm}$. in length and $2.5 \mathrm{~mm}$. in breadth; on the twelfth nerve, small nodule.

A small growth was also found attached to the dura mater in the posterior fossa, and this was found microscopically to be an endothelioma. The remainder of the brain and nervous system was normal in appearance.

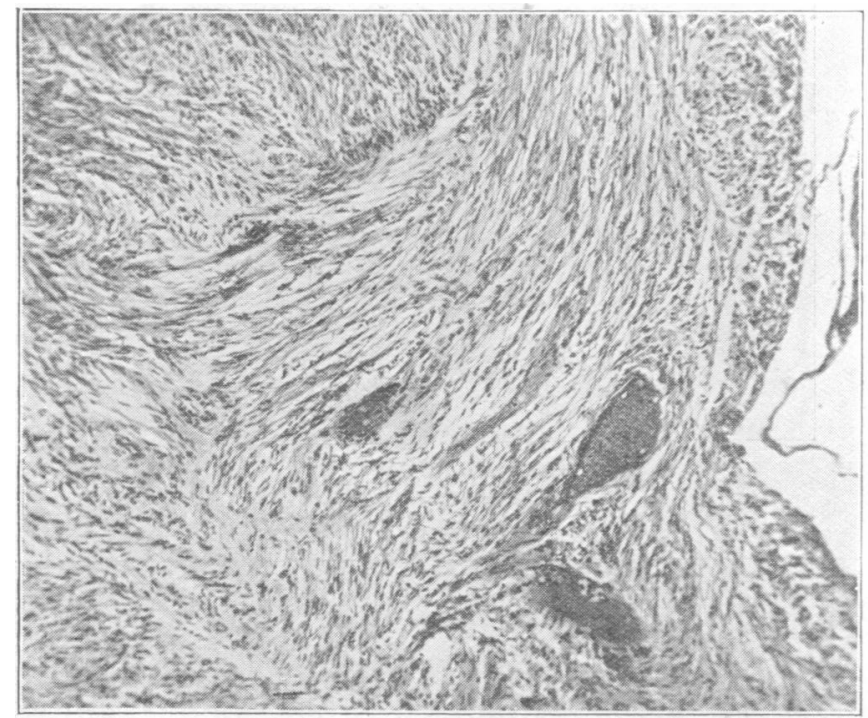

Fici. 10

Microscopical Examination.--The two large growths and the small growths on the cranial nerves were identical in character and were typical neurofibromata. They consisted of elongated cells arranged both in bundles and whorls, and presented the usual palisade arrangement (fig. 10). There were areas in the growths which were myxomatous in type. The small growths in the cranial nerves were looser in structure than the large growths and presented a more whorled appearance than the latter. This was well seen in the eighth right cranial nerve which macroscopically showed small multiple growths coalesced to form one large growth, but microscopically presented the appearance of a number of small circumscribed growths separated from each other by a thin fibrous capsule (fig. 11). A number of typical neuroglia cells were seen in the growths on the cranial nerves, but were not found in the large growths. Parts of the large growths were prepared by the Bielschowsky silver method for demonstrating nerve fibres, but the results 
were negative. In spite of staining sections in a variety of ways, no nerve fibres were found in them.

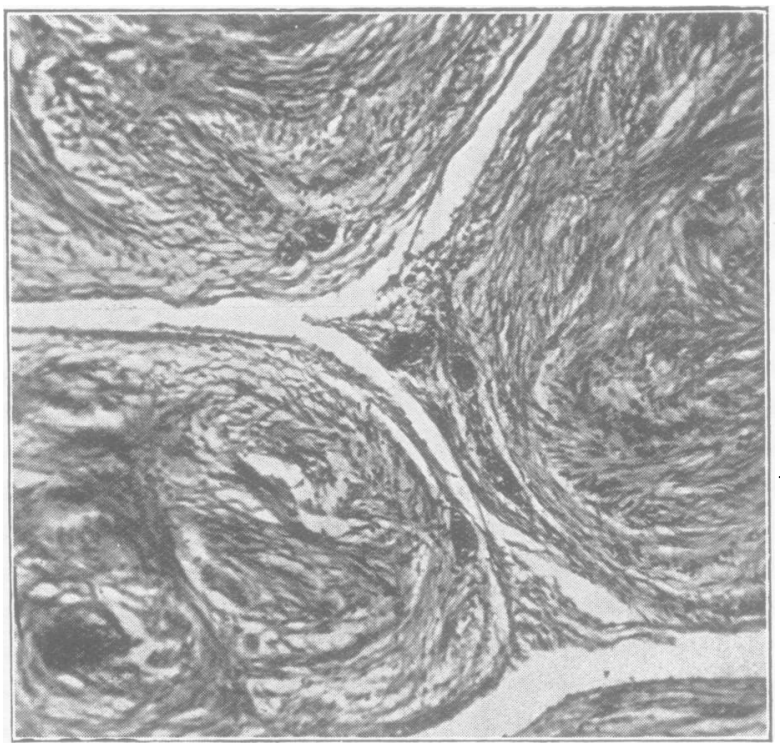

Fis: 11 .

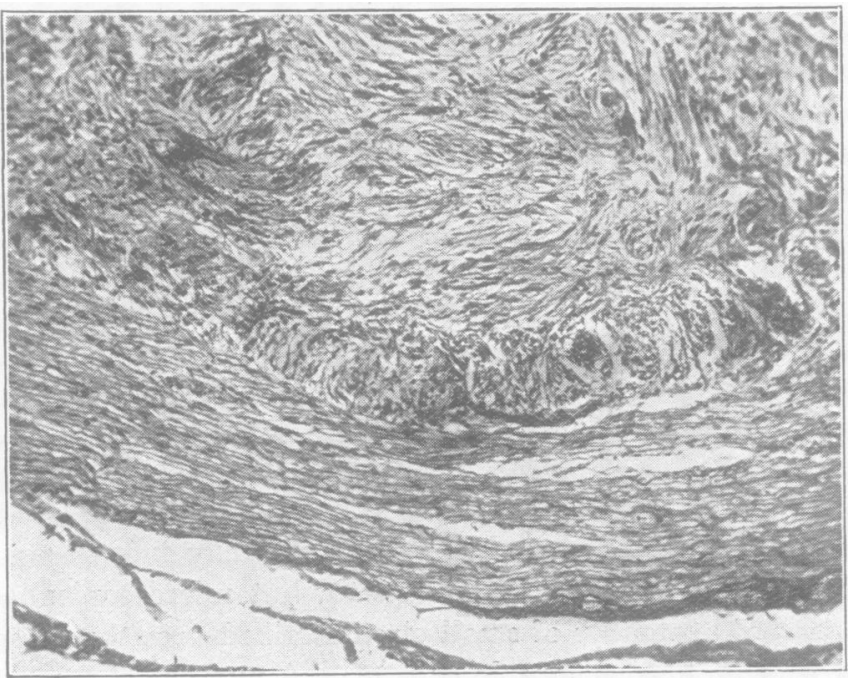

Fic. 12.

As already stated, the histological structure of the large growths and the growths in the cranial nerves was identical, but in the case of the latter 
it was possible to cut the nerve and growth in the same section and trace the relationship to each other. The small growth on the twelfth right cranial nerve could be seen attached to the nerve, and it was possible to trace the nerve to the edge of the growth where it was seen to divide into two distinct

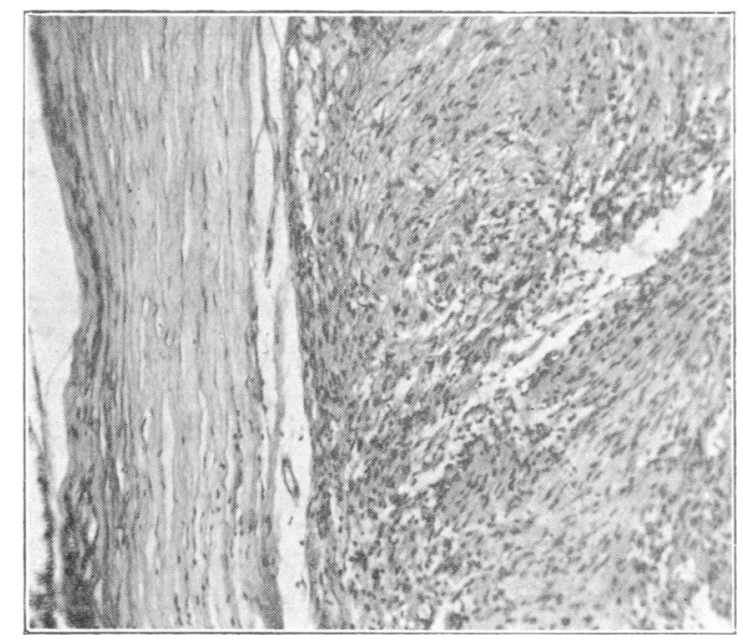

FIti. 13.

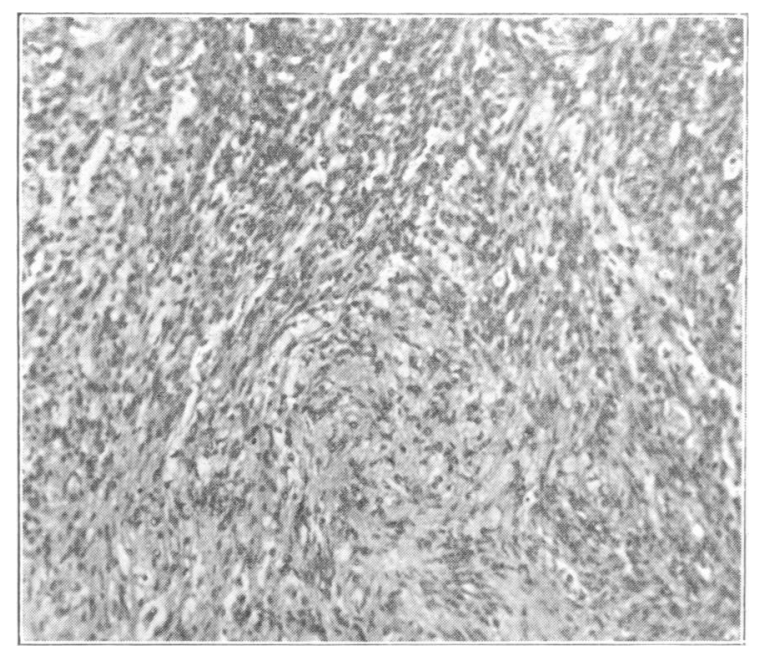

FIG. 14.

branches. One branch merged into the growth without any definite line of demarcation and the axis-cylinders ended abruptly. The other branch passed round the outer border of the growth, retaining its nervous structure, and continued on the other side of the growth (fig. 12). At the summit where 
the nerve passed over there was a small elongated area of loose reticular tissue between the more fibrous part of the growth and the nerve proper, suggesting that the growth may be derived from the neurilemma sheath. A similar appearance was noticed in the growths on the other cranial nerves.

CASE II.-The growth removed by operation from the arm in Case II was enclosed by a thick capsule of fibrous tissue (fig. 13). Its character was that of a neurofibroma and resembled the growths described in Case I, although the areas of myxomatous tissue were not so numerous (fig. 14). No myelinated nerve fibres were demonstrated by the Bielschowsky or any other method.

\section{SUMMARY.}

I. The form taken by the disease in three different members of the same generation is interesting, in that one suffered from double acoustic tumours only, one from spinal tumours only, and one from double acoustic tumours and generalized neurofibromatosis.

II. In spite of examination of most of the living members of other generations, no signs of neurofibromatosis could be found in them, and a careful search into the histories of others that were deceased brought to light no data suggesting its occurrence.

III. In all three patients a blow preceded the first signs of the disease, the trauma in each case being local; in Case I it was on the head, in Case II on the elbow, where two lumps appeared, and in Case III on the shoulder. It is probable, however, that the trauma merely first drew attention to the disease.

IV. Bone changes were present in two cases. E. B. had an osteoma of the rib removed some years ago, and pes cavus, and A. G. had a right lumbar scoliosis.

V. Motor disturbances due to local nerve involvement in the form of wasting are said by Harbitz ${ }^{31}$ to be rare and sensory changes uncommon. This he says is due to nerve-fibres persisting in the tumours without degenerating, or to a diffuse infiltration of the nerves. Case II showed marked wasting of the small muscles of the hands and of one leg and thigh, but there was no evidence of a spinal cord tumour pressing on the nerve roots as in the case of the youngest member, who died. Sensory disturbances were also present in the hands and feet in the form of anæsthesia and paresthesiæ.

VI. From the literature it will be seen that bilateral acoustic tumours with generalized neurofibromatosis are much commoner than bilateral acoustic tumours only, and that unilateral tumours are much less rare than the bilateral ones.

VII. The cerebrospinal fluid in both cases was interesting. In Case II 
the Lange curve was typically paretic. This according to Cruickshank ${ }^{33}$ and others depends on relative increase of globulin in proportion to albumin. The protein was $200 \mathrm{mgrm}$. per cent. and gave a positive Pandy, whereas the cells were only 3 per cent., giving rise to the 'dissociation albuminocytologique.' In Case I there was no increase of cells; the protein was $50 \mathrm{mgrm}$. per cent. and the Lange curve 4433210000 , showing a tendency to the same condition. Foix ${ }^{36}$ and Boveri $^{37}$ consider this to be characteristic of tumour of the brain or spinal cord, but it is by no means typical. Greenfield and Carmichael $^{38}$ think that any great increase of protein indicates that the tumour is either in the posterior cranial fossa or in close relation to the walls of the ventricles.

The same authors ${ }^{39}$ state that neurofibromata of the acoustic nerve are usually associated with increase of protein without lymphocytosis. They describe a case with $175 \mathrm{mgrm}$. protein and 1 cell, and they think that the protein has a similar origin to that in glioma of the ventricular walls and is due to transudation from the tumour into the region of the large subtentorial cisterns.

VIII. It will be seen that in this series tumours containing nerve tissue only and others with myxomatous tissue were found. The tumours were found on not only the eighth, but the seventh and twelfth nerves also, with in addition an endothelioma of the dura.

In this series no medullated nerve fibres could be found in the tumours nor were any of the changes in the nervous system mentioned by Gamper present.

I wish to thank Dr. Edward Mapother, Medical Superintendent, for permission to publish these cases, and Dr. Graham Hodgson for his kindness in preparing the tracings of the $\mathrm{X}$-ray photographs.

\section{REFERENCES.}

1 Wishart, J., ' Cases of tumours in the skull, dura mater and brain,' Edin. Med. Surg. Jour., 1822, xviii, 393.

2 KNoblauch, 'De neuromate et gangliis accessoriis,' Inaug. Dissert., Frankfort, 1843.

${ }^{3}$ Henseberg and Косн, ' ̈̈ber centrale neurofibromatose und die Geschwülste des Kleinhirnbrückenwinkels (Acusticusneurome),' Arch. f. Psychiat., 1902, xxxvi, 251.

1 v. Recklinghausen, Ueber die multiple Fibrome der Haut, 1882.

: Thomson, A., On neuroma and neurofibromatosis, 1900.

${ }^{6}$ Hensches, F., 'Die Akustikustumoren, eine neue Gruppe radiographisch darstellbarer Hirntumoren,' Fortschr. a. d. Geb. d. Röntgenstrahlen, 1912, xviii, 207.

' Grahair Hongson, ' Radiology of the normal and abnormal labyrinth,' Jour. of Laryngol. and Otol., 1928, xliii, 92.

${ }^{8}$ Brooks, B., and Lehmax, M. D., 'The bone changes in Recklinghausen's neurofibromatosis,' Surg. Gynec. Obst., 1924, xxxviii, 587.

9 Weiss, 'Curvature of the spine in von Recklinghausen's disease,' Arch. Dermat. and Syph., 1921, iii, 1.t. 
${ }^{10}$ Ashton, L. P., ' Case of von Recklinghausen's disease with spontaneous fracture,' Bristol Med. Chir. Jour., 1930, xlvii, 219.

11 Parkes Weber, ' Periosteal neurofibromatosis with a short consideration of the whole subject of neurofibromatosis,' Quart. Jour. of Med., 1930, xxiii, 151.

12 Preiser and Davenport, 'Multiple neurofibromatosis and its inheritance,' Amer. Jour. Med. Sci., 1918, clvi, 507.

${ }^{13}$ Gardner and Frazier, 'Bilateral acoustic neurofibromas,' Arch. Neurol. and Psychiat., 1930, xxiii, 266.

14 Henschen, F., Ueber Geschwülste der hinteren Schädelgrube, insbesondere des Kleinhirnbrückenwinkels, 1910.

${ }^{15}$ Cushing, H., Tumours of the Nervus Acusticus, 1917.

16 Penfield, W., 'The encapsulated tumours of the nervous system,' Surg. Gynec. Obst., 1927, xlv, 178.

${ }^{17}$ Skinner, H. Allan, ' Origin of acoustic nerve tumours,' Brit. Jour. of Surg., 1929, xv, 440.

18 Cushing, ibid.

19 Sternberg, C., 'Beitrag zur Kenntnis der sogenannten Geschwülste des N. acusticus,' Deuts. Zeits. f. Nervenheilk., 1900, xxi, 163.

${ }^{20}$ ORzEchowski, K., ' Fall von Misbildung des Laterrezessus : Ein Beitrag zur Ontologie des Kleinhirnbrückenwinkels,' Arb. a. d. neurol. Inst. a. d. Wien. Univ., 1908, xiv, 406. ii, 103.

21 Trotter, W., 'The insulation of the nervous system,' Brit. Med. Jour., 1926,

22 Kawashima, Virchow's Arch. f. path. Anat., 1911, cciii, 66.

${ }^{23}$ Roubinovitch and De La Sourdiere, quoted by Goodhart, S. P., in Practice of Medicine by Frederick TICE, 1921.

24 Barber and Shaw, Brit. Jour. Dermat. Syph., 1922, xxxiv, 239.

${ }^{25}$ LEIR, quoted by Goodhart, ibid.

26 Virchow, 'Das wahre Neuron,'Archiv. f. path. Anat., 1858., xiii, 256.

27 von ReCkLINGHaUSen, ibid.

28 Thomson, A., ibid.

29 Durante, G., 'Nerfs,' in Manuel d'anat. pathol., by CornIL and Ranvier, 1907, iii, 425.

30 Verocay, 'Zur Kenntnis der Neurofibrome,' Beit. z. path. Anat. u. z. allg. Path., 1910, xlviii, 1.

31 Cushing, ibid.

32 Greenfield, J. G., 'Pathological examination of 40 intracranial neoplasms,' Brain, 1919, xlii, 29.

${ }^{33}$ GAMPER, E., ' Zur Kenntnis der zentralen Veränderungen bei morbus Recklinghausen,' Jour. Psychol. u. Neurol., 1929, xxxix, 39.

${ }^{34}$ Harbitz, F., 'Multiple neurofibromatosis,' Arch. of Int. Med., 1909, iii, 1156.

35 Cruickshank, J., Brit. Jour. Exper. Pathol., 1920, i, 71.

${ }^{36}$ Forx, C. H., Revue neurol., 1923, xxx, 610.

37 Boveri, Il Policlinico (Sez. Pract.), 1922, xxix, 1001.

38 Greenfield and Carmichael, The Cerebrospinal Fluid in Clinical Diagnosis, 1925, 189.

39 Greenfield and Carmichael, ibid., 65. 